\title{
Model Pembelajaran Mnemonik bantu Siswa Mengingat Sejarah
}

\author{
Siti Ismirat Purnama Sari Rush \\ Program Studi Pendidikan Sejarah FKIP Universitas Lambung Mangkurat Banjarmasin
}

Email: SitiIsmirat@gmail.com

\begin{abstract}
Abstrak: Zaman sekarang sangat penting bagi kita untuk mengingat sejarah karena kita lahir setelah peristiwa penting negeri ini, terlebih untuk sejarah lokal sendiri bukan hanya dari ceritacerita orang atau lingkungan keluarga namun kita juga di sekolah. Di sekolah tentu mempelajari berbagai pelajaran salah satunya mata pelajaran sejarah atau biasanya termasuk pada mata pelajaran IPS terpadu atau pun berdiri sendiri melalui proses pembelajaran, mata pelajaran sejarah ini bertumpu pada daya ingat atau memori siswa dalam mengingat materi pelajaran.

Ketika prosses pembelajaran mata pelajaran sejarah hal paling di utamakan yaitu daya ingat, maka sudah seharusnya menggunakan model pembelajaran yang tepat untuk membantu siswa dalam mengingat sejarah, baik itu nasional dan lokal sekalipun. Dengan menggunakan model Mnemonik pendidik dapat membantu siswa untuk meningkatkan penyimpanan dan pengambilan informasi didalam atau dari memori.
\end{abstract}

Kata kunci: mnemonik, daya ingat, sejarah

\section{Pendahuluan}

Sebuah model yang tepat pada proses pembelajaran dapat membantu siswa dalam mengingat pelajarannya terlebih pada mata pelajaran sejarah, meskipun tidak mudah karena banyak yang berpikiran mata pelajaran sejarah ini membosankan karena harus mengingat banyak sejarah dan melakukan pembelajaran sesuai dengan yang diinginkan, dalam model mnemonik ini siswa bukan hanya mengingat namun juga membantu siswa menyimpan ingatan tersebut. Memori pada siswa merupakan salah satu komponen penting dalam pembelajaran, karena memori adalah tempat penyimpanan informasi dan pengetahuan dalam otak. Belajar dan memori merupakan dua hal yang saling berhubungan (Bhinnety, 2005; Buzan, 2006; dan Eysenck, 2012). Sedangkan memori tidak mungkin terpisah dari proses belajar, karena individu hanya dapat mengingat sesuatu yang dipelajari sebelumnya. Memori yang tinggi akan membuat siswa dapat menyerap pelajaran dengan baik, karena memori sebagai penyimpanan informasi atau pengalaman seiring dengan berjalannya waktu (Anshorulloh, 2008; Harianti, 2008; dan King, 2011:396). \& Fortin, 2003).

Model Mnemonik adalah model untuk memperoleh informasi dengan cara mengingat kembali dan menghafalkan. Mnemonik adalah cara yang dapat digunakan untuk meningkatkan daya ingat seseorang dalam memaknai suatu kata, gagasan atau ide melalui pengasosiasian pikiran sehingga informasi yang diperoleh dapat dengan mudah disimpan dalam memori jangka panjang. Ketika menggunakan Mnemonik maka proses ingatan akan lebih mudah dalam mengingat sesuatu. Mnemonik berasal dari kata Mnemonics yang berarti kepandaian dalam menghafal. Inti dari Model Mnemonik adalah imajinasi yang merupakan suatu proses pembentukan isyarat visual. Sebagai contoh yakni memvisualisasi pikiran mengenai suatu 
objek, peristiwa serta mempresentasikan cara bagaimana informasi berkaitan dengan pembelajaran baru dapat disimpan dalam memori otak.

Ketika dalam proses pembelajaran seorang pendidik tentunya menggunakan sebuah model pembelajaran pada mata pelajaran sejarah pasti pendidik menginginkan siswa nya bisa mengingat dan menyimpan informasi yang didapatkannya terlebih pada mata pelajaran sejarah, mengingat merupakan hal utama dan merupakan bagian pada model pembelajaran mnemonik.

Pentingnya sebuah proses pembelajaran tersebut, sudah selayaknya pembelajaran sejarah menggunakan model pembelajaran yang membantu siswa nya mengingat sejarah yang telah dipelajarinya, model pembelajaran menentukan keberhasilan pencapaian

\section{Model pembelajaran mnemonik dalam proses pembelajaran}

Model adalah seperangkat prosedur pembelajaran untuk mewujudkan suatu proses yang meliputi penilaian kebutuhan guru dan siswa, pemilihan media pembelajaran dan evaluasi. Sedangkan model pembelajaran adalah suatu desain pembelajaran yang menggambarkan proses rincian dan penciptaan situasi lingkungan dimana siswa dapat berinteraksi sehingga terjadi perubahan atau perkembangan pada siswa.

Menurut Ridwan Abdullah Sani, model pembelajaran merupakan suatu pola prosedur sistematik dalam suatu kerangka konseptual yang dikembangkan yang didasarkan pada teori dan digunakan dalam mengorganisasikan suatu proses belajar mengajar untuk mencapai tujuan pembelajaran.

Joyce dan Weil mendefinisikan model pembelajaran sebagai kaerangka konseptual yang digunakan sebagai pedoman dalam melakukan pembelajaran. Model pembelajaran merupakan kerangka konseptual yang menggambarkan prosedur yang secara sistematis mengorganisasikan pengalaman belajar peserta didik untuk mencapai tujuan belajar tertentu. Model pembelajaran cenderung dianggap sulit untuk dibedakan dengan strategi pembelajaran. Model pembelajaran merupakan bentuk proses pembelajaran yang tergambar dari awal sampai akhir yang disajikan oleh seorang guru yang di dalamnya membungkus penerapan dari suatu pendekatan, metode dan teknik pembelajaran.

Model pembelajaran Mnemonik adalah asosiasi, menurut Kamus Besar Bahasa Indonesia asosiasi diartikan sebagai tautan dalam ingatan seseorang atau barang lain, yakni sebuah proses pembentukan hubungan antara gagasan, ingatan atau kegiatan.

Model Mnemonik merupakan suatu model pengembangan pembelajaran dalam rangka memudahkan siswa untuk mengingat suatu informasi yang diterima dengan menggunakan alat ungkit atau kaitan-kaitan dalam menghafal suatu pengetahuan sehingga proses belajar pembelajaran akan semakin mudah dan efektif.

Dari beberapa penjelasan diatas dapat disimpulkan bahwa Model Mnemonik adalah cara mengajar guru untuk memudahkan siswa menginga dan menghafal sebuah informasi yang diterima dengan mengubah ingatan jangka pendek menjadi ingatan jangka panjang. Berbicara tentang model menghafal.mnemonik, tidak terlepas dari memori atau ingatan yang merupakan sebuah kemampuan untuk menyimpan dan mereproduksi kembali hal-hal yang pernah diketahui. Beberapa sifat ingatan tersebut dimaksudkan sebagai berikut:

1) Ingatan cepat, yakni mudah dalam mencamkan sesuatu hal tanpa menjumpai kesukaran.

2) Ingatan setia, yakni apa yang telah diterima atau dicamkan akan disimpan sebaik-baiknya dan tidak akan berubah-ubah sehingga tetap cocok dengan keadaan waktu menerimanya. 
3) Ingatan teguh, yakni menyimpan kesan atau informasi dalam waktu yang lama dan tidak mudah lupa.

4) Ingatan luas, yakni dapat menyimpan banyak kesan atau informasi

5) Ingatan siap, yakni mudah dalam mereproduksi kesan yang telah disimpannya.

Model pembelajaran Mnemonik adalah suatu model dengan sistem menghafal dengan teknik tertentu, diantaranya :

1) Kesadaran (awareness)

Menurut Lorayne dan Lucas bahwa segala sesuatu yang disadari akan sangat sulit untuk dilupakan termasuk materi yang benar-benar dipahami peserta didik dalam proses belajar pembelajaran

2) Asosiasi (Association)

Aturan dasar dalam menghafal adalah mengingat dengan cara mengasosiasikannya dengan sesuatu yang sudah dikenal dan diingat sebelumnya. Misalnya ketika guru akan menjelaskan teori geosentris yang berkembang dalam teori jagad raya, maka guru memberikan asosiasi antara kata geo dengan makna bumi. Hal ini dilakukan dengan tujuan agar peserta didik lebih cepat paham dan mengingat teori geosentris yaitu teori yang menyatakan bahwa bumi sebagai pusat segalanya.

3) Sistem Link (Link System)

Inti dari prosedur memori adalah menyambungkan dua gagasan yang memicu gagasan lain dan seterusnya.

\section{4) Asosiasi Konyol (Ridiculous Association)}

Kekuatan asosiasi dapat diperbesar dengan mewujudkan gambar yang jelas dan lucu, sesuatu yang tidak mungkin atau tidak masuk akan. Beberapa cara untuk membuat asosiasi menjadi lucu diantaranya dengan menerapkan substitusi/penggantian, menerapkan aturan ketidakseimbangan, membuat hal-hal yang kecil menjadi besar atau sebaliknya, dan yang terakhir adalah dengan membuat aturan tindakan yang membesar-besarkan.

5) Sistem Kata Ganti (Substitute Word System)

Yakni merupakan suatu cara untuk membuat hal-hal yang tidak dapat disentuh menjadi sesuatu yang tidak dapat disentuh dan bermakna. Misalnya ketika guru akan memahamkan siswa tentang konsep de facto maka guru mengganti kata facto menjadi fakta. Sensus defacto adalah cara perhitungan jumlah penduduk yang dikenakan kepada setiap orang pada waktu sensus yang berada di wilayah sensus. Jadi defacto (faktanya) adalah penduduk tersebut berada di wilayah sensus.

6) Kata Kunci (Key Word)

Dalam sistem kata kunci adalah memilih satu kata untuk mempresentasikan pemikiran atau beberapa yang lebih panjang. Misalnya untuk membantu peserta didik mengingat urutan planet maka guru membuat kata kunci menarik yakni Mevebumayusa yang merupakan singkatan dari Merkurius, Venus, Bumi, Mars, Yupiter, Saturnus.

Tujuan Model Mnemonik

Beberapa tujuan pembelajaran Mnemonik adalah dapat mempermudah siswa dalam mengingat suatu informasi atau pengetahuan dengan cara menghubungkan dan mengasosiasikan dengan suatu kejadian yang dekat dan memiliki hubungan dengan dirinya. 
Model Mnemonik juga dapat mempermudah seseorang dalam mengingat kembali pengetahuan yang sudah lama masuk ke dalam memori untuk kemudian diungkap kembali apabila diperlukan. Serta Model Mnemonik ini juga dapat mengaktifkan informasi dari ingatan jangka pendek menjadi ingatan jangka panjang dengan berbagai cara yang ada di dalamnya.

Dalam penerapan Model Mnemonik, siswa dituntuk untuk menggunakan daya ingat yang dimilikinya. Dalam Model Mnemonik siswa tidak lebih dari dituntut untuk menggunakan kemampuan berfikirnya untuk mengasosiasikan kata-kata, gagsan atau ide dengan sebuah gambaran. Mnemonik secara singkat diartikan sebagai bantuan ingatan.

\section{Langkah-langkah Mnemonik}

Menurut Miftakhul Huda Model Pembelajaran Mnemonik memiliki beberapa sintak atau langkah-langkah dalam pelaksanaan pembelajarannya yang harus diperhatikan diantaranya sebagai berikut:

1) Tahap 1 yakni tahap mempersiapakan materi.

Pada tahap ini kegiatan siswa diantaranya yakni menggaris bawahi, membuat daftar dan terakhir adalah merefleksikan.

2) Tahap 2 yakni mengembangkan hubungan-hubungan.

Dalam tahap ini siswa membuat sendiri materi menjadi lebih familiar dengan menggunakan teknik menghubungkan dengan kata penghubung yang tepat. Selaian menggunakan kata penghubung dapat juga dengan menggunakan teknik seperti penggunaan kata kunci, dan kata ganti.

3) Tahap 3 yakni memperluas gambar sensorik

Siswa diminta untuk mengasosiasikan gambar dengan indera serta menciptakan dramatisasi dengan asosiasi yang lucu (ridiculous association) dan melebih-lebihkan (exaggeration).

4) Tahap 4 yakni mengingat kembali

Pada tahap ini siswa diminta untuk mengulang atau mengingat kembali materi yang sudah disampaikan sehingga semua materi dapat tuntas dikuasai.

Berdasarkan penjelasan di atas pada tahapan model pembelajaran mnemonik dapat menggambarkan bagaimana proses pembelajaran terjadi diawali dengan menyediakan materi atau bahan ajar yang akan disampaikan dengan teknik menggaris bawahi kosakata-kosakata yang sulit serta membuat daftar kosakata yang sudah ditemukan. Pada tahap kedua menghubungkan antar materi semenarik mungkin agar mudah dihafalkan oleh siswa yang kemudian dikembangkan dengan menggunakan teknik kata kunci, kata ganti, kata hubung atau mengkategorikannya. Tahap ketiga mempertajam ingatan siswa tentang informasi yang telah diperoleh dengan menggunakan kata-kata yang lucu atau menarik bagi siswa atau menggunakan kata-kata yang melebih-lebihkan sehingga siswa akan mudah untuk mengingatnya. Tahap yang terakhir mengulang materi yang telah disampaikan oleh guru sampai materi benar-benar difahami oleh siswa.

Model pembelajaran Mnemonik ini menggunakan strategi pembelajaran ekspositori yang menekankan pada proses penyampaian materi secara verbal dari guru kepada siswa dengan tujuan memudahkan siswa dalam menguasai materi yang disampaikan.

Macam-macam metode dalam Model Mnemonik 
Dalam Model Mnemonik terdapat beberapa metode yang dapat digunakan dalam proses belajar mengajar untuk memudahkan dalam penyerapan materi:

1) Rima (Rhyme) Dengan metode ini materi kosakata yang diberikan kepada siswa diberikan dan dikemas dengan menggunakan sajak agar mudah diingat oleh siswa yang mana sajak tersebut diberi not-not sehingga dapat dinyanyikan. Nyanyian-nyanyian anak-anak dapat digunakan sebagai referensi contoh penyusunan rima mnemonik.

2) Sistem Kata Pasak (Page Word System) Sistem kata pasak ini dilakukan dengan menggunakan kata atau komponen yang sudah dikuasai oleh anak sebelumnya (prior knowledge) seperti pasak (paku) mengingat memori baru. Sistem pasak ini menggunakan kata komponen pasak yang dibentuk berpasang-pasangan misalnya kuning-bunga matahari, dingin-salju. Kata ini berguna untuk membantu siswa dalam mengingat kata dan istilah yang memiliki sifat yang sama.

3) Metode Losai (Method of Loci) Dengan metode losai yakni menggunakan tempattempat khusus yang dikenal siswa sebagai sarana penempatan koskata yang harus diingat oleh siswa. Dalam hal ini bisa menggunakan nama kota, jalan, gedung terkenal yangs sering dipakai dan familiar bagi siswa yang relevan dalam arti memiliki kemiripan ciri atau keadaan.

4) Sistem Kata Kunci (Key Word System). Sistem kata kunci digunakan untuk mempelajari kata asing yang mana dalam hal ini untuk mempelajari Bahasa Inggris. Sistem ini berbentuk daftar kata yang terdiri dari unsur-unsur seperti kata-kata asing, kata-kata kunci yakni kata bahasa lokal yang paling mirip dengan istilah asing yang sedang dipelajari serta arti-arti asing tersebut.

5) Teknik Kata Penghubung. Membuat hubungan yang logis dan realistis dengan mengaitkan atau mengasosiasikan satu kata dengan kata lain melalui sebuah aksi atau gambaran yang dapat memicu ingatan siswa.

\section{Mnemonik dalam mata pelajaran sejarah}

Model mnemonik disebut juga bantuan memori. Menurut Joyce, Weil dan Calhoun (2011), model ini dirancang untuk membantu siswa dalam mengingat materi pembelajaran yang berupa fakta, peristiwa atau nama. Cara yang dipakai adalah menggarisbawahi, membuat perumpamaan yang menarik, atau membuat kata ganti, dalam istilah lain sering disebut “jembatan keledai”. Mnemonik merupakan model pembelajaran yang menyenangkan, akan tetapi model ini memang tidak melatih siswa untuk penguasaan aspek kognitif tingkat tinggi. Joyce (1996) mengungkapkan beberapa tahap yang dapat meningkatkan daya ingat dalam mnemonic. Contoh aplikasi dalam pembelajaran sejarah:

- Langkah 1; mempersiapkan materi

Istilah-istilah sulit atau penting dalam materi dibuat daftar

- Langkah 2; mengembangkan hubungan-hubungan

Siswa diminta untuk membuat jembatan keledai; membuat perumpamaan, singkatan, kata kunci atau kata ganti untuk istilah-istilah tersebut. Misalnya untuk tokoh "Tiga Serangkai" disingkat menjadi SuDoCi (Suwardi Suryaningrat, Douwes Dekker dan Cipto Mangoen Koesoemo).

- Langkah 3; memperluas gambaran sensorik 
Bisa dilakukan dengan membuat/mencari gambar yang sesuai dengan kata atau singkatan yang dibuat.

- Langkah 4; mengingat kembali

Dapat dilakukan dengan melafalkan singkatan yang dibuat dan maknanya, sehingga materi dapat diingat.

Dalam bukunya Joyce, Weil dan Calhoun (2011), mengemukakan bahwa sebaiknya prakarsa dalam kegiatan ini lebih ditekankan pada siswa, sehingga siswa mampu membuat formulasi sendiri untuk memudahkan mereka mengingat materi pelajaran.

Teknik mnemonik cukup efektif dalam membantu seseorang untuk mengingat. Meski begitu metode mnemonik tidak menjamin informasi yang masuk akan tetap diingat, sebab untuk menyimpan informasi ke dalam memori jangka panjang setidaknya butuh banyak pengulangan, terlebih pada siswa yang sedang mempelajari mata pelajaran untuk sekedar mempelajarinya saja kadang mereka bosan apalagi untuk mengingatnya.

Model pembelajaran yang membosankan pada mata pelajaran sejarah membuat siswa tidak fokus dan memperhatikan pada pelajaran, yang mana dalam belajar sebuah perhatian atau memperhatikan pelajaran adalah sebuah nilai penting dalam belajar.

Penyebab dari kurang nya perhatian siswa terhadap mata pelajaran ada dua faktor, yang pertama itu dari eksternal yaitu dari luar siswa dimana sang pendidik kurang kreatif dalam menyampaikan materi sehingga membuat siswa nya malas memerhatikan, bukan hanya dari eksternal dari internal pun juga ada yaitu pada siswa sendiri yang mengalami kesulitan untuk menghapal sederet peristiwa dan fakta yang harus dihapal.

Dari berbagai tahap atau langkah dan metode pada model pembelajaran mnemonik ini siswa bisa mengingat pentingnya sebuah sejarah yang mampu merubah negeri ini dan menjadikan sejarah itu sebagai pelajaran dan acuan untuk menjadi lebih baik lagi dimasa depan

\section{PENUTUP}

Model pembelajaran Mnemonik adalah cara mengajar guru untuk memudahkan siswa menginga dan menghafal sebuah informasi yang diterima dengan mengubah ingatan jangka pendek menjadi ingatan jangka panjang. Berbicara tentang model menghafal.mnemonik, tidak terlepas dari memori atau ingatan yang merupakan sebuah kemampuan untuk menyimpan dan mereproduksi kembali hal-hal yang pernah diketahui.

Untuk membantu siswa dalam mengingat pembelajaran terlebih pada mata pelajaran sejarah sangat dianjurkan menggunakan model pembelajaran yang tepat karena ketika siswa belajar mata pelajaran sejarah siswa terkadang merasa bosan dan dengan cepat melupakan pelajaran yang dipelajarinya pada hari itu

\section{DAFTAR PUSTAKA}

\section{A. Buku}

Joyce, Bruce dkk. 2011. Models of Teaching (Model-model Pengajaran) Edisi kedelapan. Yogyakarta: Pustaka Belajar

Hamruni. 2012. Strategi Pembelajaran, Yogyakarta:Insan Madani. 
Huda, Mifatkhul. 2013. Model-model Pengajaran. Yogyakarta: Pustaka Pelajar.

M Syarif Sumantri. 2015. Teori dan Praktik di Tingkat Pendidikan Dasar. Jakarta : PT Rajagrafindo Persada.

Rahman, Muhammad \& Sofan Amri. 2013. Strategi dan Desain Pengembangan Sistem Pembelajaran. Jakarta: Prestasi Pustaka Karya.

Sani, Ridwan Abdullah. 2013. Inovasi Pembelajaran. Jakarta: Bumi Aksara.

Suryabrata, Suradi. 1998. Psikologi Pendidikan. Jakarta: PT Raja Grafindo Persada.

Susanto, Heri. 2014. Seputar Pembelajaran Sejarah: Isu, Gagasan dan Strategi dalam Pembelajaran. Yogyakarta: Aswaja Pressindo.

Suyadi. 2014. Teori Pembelajaran Anak Usia Dini. Bandung: PT Remaja Rosdakarya

Syah, Muhibbin. 2013. Psikologi Pendidikan dengan Pendekatan Baru. Bandung : PT Remaja Rosdakarya.

Tim Penyusun Kamus Pusat Bahasa. 2002. Kamus Besar Bahasa Indonesia. Jakarta:Balai Pustaka.

\section{B. Hasil Penelitian, Jurnal dan Makalah/Prosiding:}

Eslandi, Feri, 2017. Pengaruh Model Mnemonik Terhadap Hasil Belajar Kognitif IPS Siswa Kelas VIII Pada SMP Negeri 1 Katibung Tahun Ajaran 2015/2016. Universitas Lampung: Pendidikan Sejarah. Skripsi.

Fauzi, Arif Irfan. 2015. Pengembangan Model Mnemonik Untuk Meningkatkan Kemampuan Menulis Teks Cerpen Pada Siswa Kelas VII. Universitas Negeri Malang: Pendidikan Bahasa Indonesia. Tesis tidak diterbitkan).

\section{Jurnal}

Hasyim, Maylita \& Sudjono, M.Joang Equator. 2015. Perbandingan Hasil Belajar Matematika Melalui Eksperimental Metode Mind Mapping dan Metode Mnemonik Ditinjau dari Tingkat Kemampuan Memori Siswa. Vol. 1, No 2 Jurnal Pendidikan dan Pembelajaran https://jurnal.stkippgritulungagung.ac.id/index.php/jp2m/article/view/189 diakses pada 22 april 2020 22:29wita. 
Purnamasari, Rika. 2018. Strategi Pembelajaran Mnemonic untuk Meningkatkan Memori Siswa" in SIPATAHOENAN: South-East Asian Journal for Youth, Sports \& Health Education. Vol 4 No 2, Bandung, Indonesia: Minda Masagi Press owned by ASPENSI with a print-ISSN $2407-7348$.

https://www.google.com/url?sa=t\&rct=j\&q=\&esrc=s\&source=web\&cd=1\&cad=rja\&uac $\mathrm{t}=8 \&$ ved=2ahUKEwjd58yrkProAhXulEsFHaQJAsIQFjAAegQIAxAB\&url=http\%3A\% 2F\%2Frepo.iain-

tulungagung.ac.id\%2F10126\%2F9\%2FDAFTAR\%2520RUJUKAN.pdf\&usg=AOvVaw 3Mtwe0JSUnotEYP7vWkUYG diakses pada 19 April 2020 22:39wita. 